\title{
QUEUEING THEORY
}

\section{Worked examples and problems}

\author{
J. Murdoch
}

Head of Statistics and Operational Research Unit, School of Production Studies,

Cranfield Institute of Technology 
All rights reserved. No part of this publication may be reproduced or transmitted, in any form or by any means, without permission.

First published 1978 by

THE MACMILLAN PRESS LTD

London and Basingstoke

Associated companies in New York Dublin

Melbourne Johannesburg and Madras

ISBN 978-1-349-03313-3 ISBN 978-1-349-03311-9 (eBook)

DOI 10.1007/978-1-349-03311-9

This book is sold subject to the standard conditions of the Net Book Agreement.

The paperback edition of this book is sold subject to the condition that it shall not, by way of trade or otherwise, be lent, resold, hired out, or otherwise circulated without the publisher's prior consent in any form of binding other than that in which it is published and without a similar condition including this condition being imposed on the subsequent purchaser. 


\section{CONTENTS}

Preface v v

Glossary of symbols vi

Classification of Queueing systems viii

1. BASIC CONCEPTS OF QUEUES 1

1.1 Introduction 1

1.2 The Queueing Situation 1

1.3 Types of Queueing Problem 3

1.4 The Basic Theory 3

1.5 Mathematical Solution of Queueing Problems 8

2. BASIC DISTRIBUTIONS IN QUEUEING THEORY 10

2.1 Introduction 10

2.2 Résumé of Basic Theory and Formulae 10

2.3 Problems 12

2.4 Solutions 13

3. $M / M / 1 / \infty$ SYSTEMS 18

3.1 Introduction 18

3.2 Résume of Basic Theory and Formulae 18

$\begin{array}{ll}3.3 \text { Problems } & 19\end{array}$

3.4 Solutions $\quad 22$

4. M/M/1/N SYSTEMS 33

4.1 Introduction 33

4.2 Résumé of Basic Theory and Formulae 33

4.3 Problems 38

4.4 Solutions $\quad 40$

5. M/M/C/ $\infty$ SYSTEMS 46

5.1 Introduction $\quad 46$ 
5.2 Resume of Basic Theory and Formulae 46

5.3 Problems 47

5.4 Solutions $\quad 50$

6. SYSTEMS WITH ARRIVAL RATE AND/OR SERVICE RATE 62

DEPENDENT ON THE NUMBER IN THE SYSTEM $\left(M_{n} / M_{n} /-/-\right)$

6.1 Introduction $\quad 62$

6.2 Résume of Basic Theory and Formulae 62

6.3 Special Apnlications of Theory 63

6.4 Problems 65

$\begin{array}{lll}6.5 & \text { Solutions } & 67\end{array}$

7. SINGLE-CHANNEL SYSTEMS WITH GENERAL SERVICE TIME

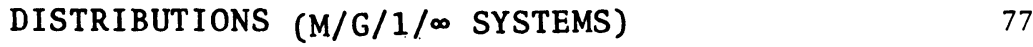

$\begin{array}{lll}7.1 & \text { Introduction } & 77\end{array}$

7.2 Resume of Basic Theory and Formulae 77

$\begin{array}{lll}7.3 & \text { Problems } & 77\end{array}$

$\begin{array}{lll}7.4 & \text { Solutions } & 78\end{array}$

statistical Tables

Table 1 Poisson Distribution 81

Table 2 Negative Exponential Distribution 86

Table 3 optimum value of $\rho$

for $M / M / 1 / N$ Systems $\quad 87$

$\begin{array}{ll}\text { References } & 88\end{array}$ 


\section{PREFACE}

The basic concepts and an understanding of modern queueing theory are requirements not only in the training of operational research staff, management scientists, etc., but also as fundamental concepts in the training of managers or in mangement development programmes.

The efficient design and operation of 'service functions' is one of the main problems facing management today and the understanding obtained from a study of queueing theory is assential in the solution of these problems.

Industry and commerce have for too long concentrated their main resources on designing and operating the 'production units' and little attention has been paid until recently to the 'service units'. Basic concepts such as increased efficiency is achieved when the utilisation of service units is reduced' are still hard for practical personnel to understand, brought up as they are on the concept of 'maximising the utilisation' of their facilities. The ancient Chinese civilisation had a system based on queueing theory: 'Pay your doctor only when you are we11'. Thus in industry if a system is correctly designed, management should be happy when 'its maintenance gang is playing cards' since there are no breakdowns to be repaired!

This book, by concentrating on problems with their fully worked-out solutions, gives students of queueing theory not only a chance to test their understanding of the theory, but also illustrates the wide range of application of the theory.

The book covers the steady-state solutions of randomarrival queueing systems. It is designed to meet the needs not only of management science training programmes, but also of mangement teaching programmes. 


\section{GLOSSARY OF SYMBOLS}

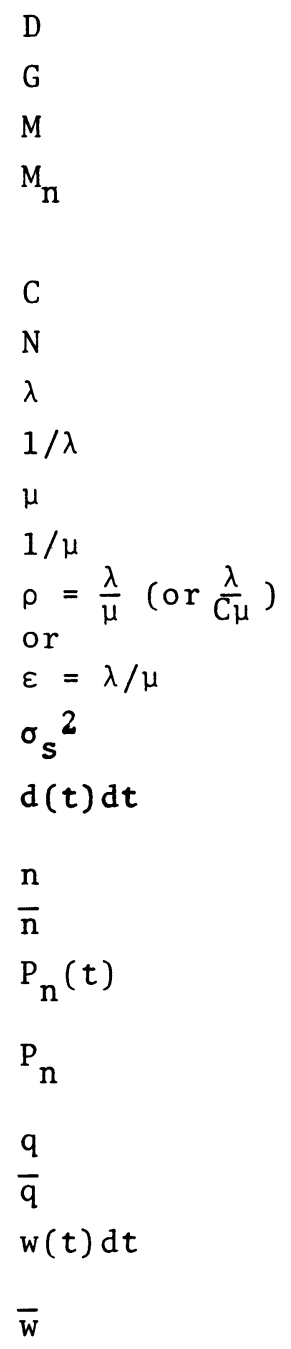

deterministic distribution

general distribution

negative exponential distribution

negative exponential distribution with mean dependent on the number in the system $n$

number of channels

maximum system size in finite queues

average arrival rate

average inter-arrival time

average service rate

average service time

intensity of traffic for single and multi-channel queues

traffic offering (multi-channel queues) variance of service time

distribution of the time in the system (steady state)

number in the system

average number in the system

transient state probabilities of $n$

in the system

steady-state probabilities of $\mathrm{n}$ in the system

number in the queue

average number in the queue

distribution of the waiting time in the queue in the steady state average waiting time of all customers in the queue in the steady state.

BASIC DISTRIBUTIONS

$$
P(x)=\frac{e^{-m_{m} x}}{x !}
$$

Poisson distribution (mean $=\mathrm{m}$ ) 
$P(t)=\frac{1}{T} e^{-t / T} d t$

Negative exponential distribution $($ mean $=\mathrm{T}$ ) 


\section{CLASSIFICATION OF QUEUEING SYSTEMS}

Queues are classified in the book as follows.
(1) /
(2) $/$
(3) $/$
(4)

(1) Input Distribution

e.g. $M, D, M_{n}, G$, etc.

(2) Service vistribution

e.g. G, D, M, etc.

(3) Number of Service Channels

e.g. $1,2, \ldots$, etc.

(4) Number in the system

Unconstrained $\infty$, finite,

EXAMPLES OF USE OF CLASSIFICATION SYSTEM

Thus an $M / M / 1 / \infty$ system is random arrival, negative exponential service time distribution, single-channel, no constraint on queue size.

Again a $G / M / C / N$ system is general arrival distribution, negative exponential service distribution, C service channels, maximum number in the system $\mathrm{N}$.

The service mechanism in all problems, is service in order of arrival, or first-in, first-out (FIFO) system. 